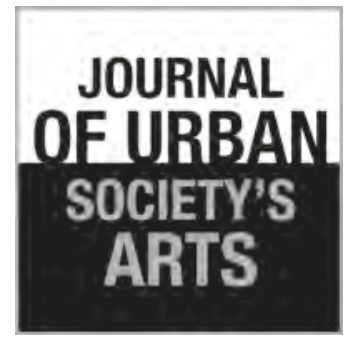

Volume 5 Nomor 1, April 2018: 11-18

\section{Ekspresi Dominasi Melalui Karya Rupa dengan Material Sampah Plastik (Refleksi terhadap Permasalahan Lingkungan di Kawasan Ciroyom Kota Bandung)}

\author{
Taufan Hidayatullah, Setiawan Sabana, dan Tisna Sanjaya \\ Program Studi Seni Rupa dan Desain, Fakultas Seni Rupa dan Desain \\ Institut Teknologi Bandung \\ Jln. Ganesha 10 Bandung \\ Tlp.081220551601, E-mail: taufanhidayatullah0210@gmail.com
}

\begin{abstract}
ABSTRAK
Dari penelitian yang telah dilakukan di kawasan pemukiman Ciroyom Kota Bandung ditemukan permasalahan lingkungan yang ditimbulkan oleh sampah plastik. Permasalahan ini muncul karena perilaku masyarakat yang cenderung masih membuang sampah plastik tanpa ada upaya-upaya untuk mengolah terlebih dahulu. Dampak negatif yang muncul adalah semakin bertambahnya volume sampah plastik yang kemudian menimbulkan permasalahan lingkungan yang lebih luas lagi. Permasalahan ini menginspirasi penciptaan karya rupa dengan menggunakan material sampah plastik.Penggunaan sampah plastik sebagai material karya seni rupa bertujuan untuk menghasilkan citra visual yang dapat menyampaikan pesan mengenai permasalahan lingkungan. Proses penciptaan dilakukan melalui tahaptahap informasi, elaborasi, sintesis, relisasi konsep dan penciptaan karya. Hasil karya berupa lukisan dengan teknik kolase yang menggunakan sampah plastik sebagai material utama.
\end{abstract}

Kata kunci: ekspresi; karya rupa; sampah plastik

\begin{abstract}
There are environmental problems that are caused by plastic waste from the research that has been carried out in Ciroyom residential area of Bandung City. These problems arise because of the behavior of the people who tend to still throw plastic waste without any efforts to process it in advance. The negative impact that arises is the increasing volume of plastic waste which then causes wider environmental problems. This problem inspires the creation of visual art by using plastic waste material. The use of plastic waste as a material of visual art aims to produce visual images that can convey messages about environmental problems. The creation process is carried out through the stages of information, elaboration, synthesis, conceptualization and creation of works. The art work is in the form of paintings with collage techniques that uses plastic waste as the main material.
\end{abstract}

Keywords: expressopm; visual art; plastic waste

\section{Pendahuluan}

Fenomena lingkungan hidup banyak menginspirasi penciptaan karya seni rupa dari masa lalu sampai saat ini melalui sajian karya yang lebih variatif. Tema lingkungan hidup menjadi tema yang banyak diangkat karena memungkinkan dilakukannya interpretasi yang lebih luas dengan beragam sudut pandang. Menafsir lingkungan hidup dalam wujud pemandangan alam yang elok dan indah banyak dilakukan oleh para perupa. Para perupa lainnya, menghadirkan lingkungan hidup dalam karya seni rupa sebagai ungkapan spiritualitasyang memiliki tujuanyang sifatnya transedental.Sementara perupa yang lainnya mengambil perspektif yang lebih kritis terhadap 
kondisi lingkungan hidup yang semakin terbebani oleh aktivitas manusia.

Perupa sebagai manusia yang menjadi bagian utuh dari suatu lingkungan hidup berupaya memberikan kontribusi yang positif melalui penghadiran karya rupa ditengah masyarakat dengan tujuan tidak semata-mata pencapaian nilai estetis visual belaka tetapi berupaya menyampaikan pesan tentang pentingnya menghargai lingkungan hidup. Seni tidak akan seketika dapat memberikan perubahan dalam cara pandang masyarakat tetapi dapat menjadi pemicu munculnya kesadaran dalam diri manusia sehingga dapat membangun empati terhadap suatu keadaan lingkungan hidup.

Faktanya lingkungan hidup saat ini menghadapi permasalahan berat yang membutuhkan penanganan serius. Industrialisasi yang tidak diikuti oleh kesadaran, kearifan dan tanggung jawab untuk meminimalkan dampak dari proses industri menghasilkan efek buruk yang semakin sulit dikendalikan. Maka yang dapat disaksikan kemudian adalah pencemaran lingkungan hidup dengan berbagai polutan padat, cair atau gas. Perilaku manusia sebagai individu maupun

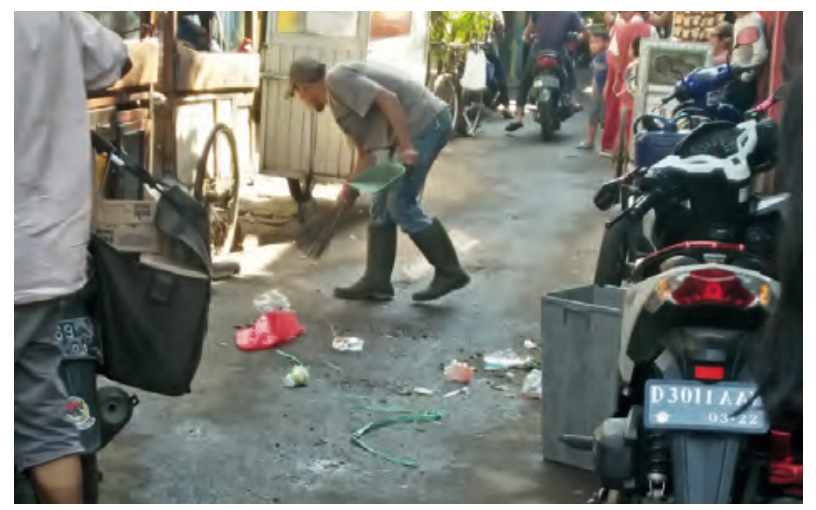

Gambar 1. Petugas kebersihan RW 04 Ciroyom yang sedang membersihkan sampah dan sampah domestik yang dikumpulkan dalam kantong plastik. (Sumber: dokumentasi pribadi)
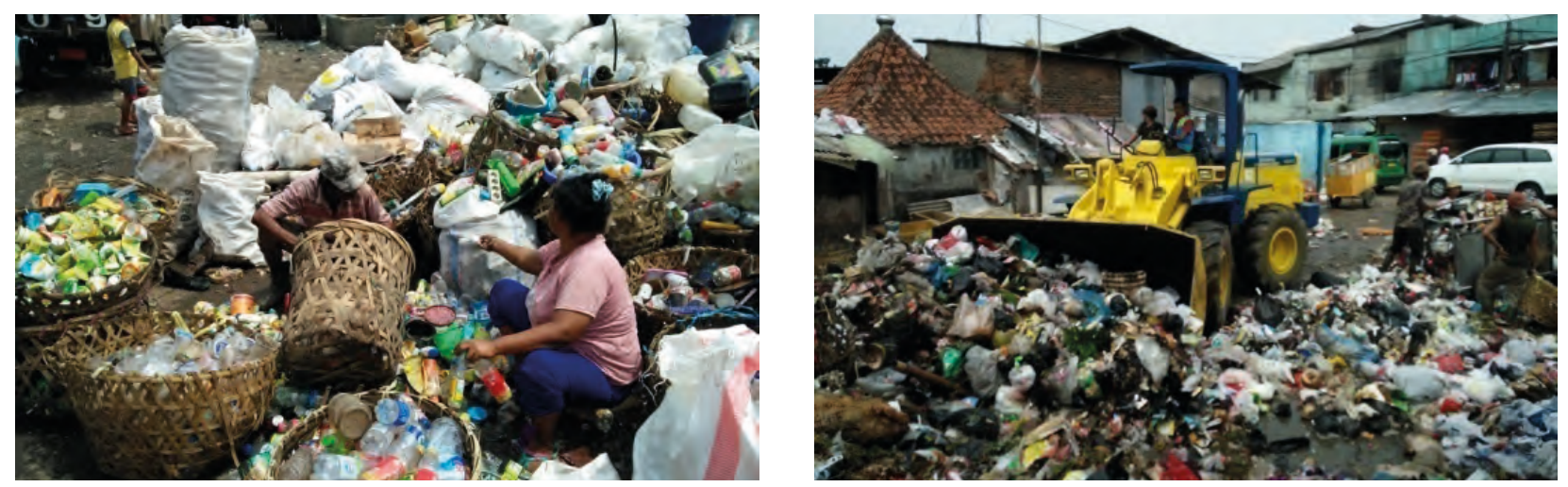

Gambar 2. Suasana di TPS Ciroyom. (Sumber: dokumentasi pribadi) 
Sampah plastik menjadi permasalahan besar di kota-kota besar. Dari pengamatan yang dilakukan di salah satu tempat pembuangan sampah sementara (TPS) di kota Bandung yaitu di TPS Ciroyom, sampah plastik cukup dominan. Sebagian sampah plastik mengandung nilai ekonomi sehingga dipisahkan oleh pemulung untuk kemudian dijual. Tetapi terdapat jenis sampah plastik lainnya yang nilai ekonomi sangat rendah sehingga diabaikan, yaitu kantong plastik (keresek) dan kemasankemasan dari produk consumer good. Bersama dengan sampah anorganik, sampah plastik yang tidak bernilai ekonomi ini kemudian diangkut ke tempat pembuangan sampah terakhir (TPA). Fakta yang teramati ini menarik untuk diangkat menjadi gagasan awal untuk penciptaan karya seni rupa.

\section{Kajian Teori \\ Sikap dan Perilaku Sosial}

Sikap (attitude) berkaitan dengan bagaimana seorang individu menanggapi dengan cara yang khas terhadap stimulus yang muncul dalam suatu lingkungan sosial. Sikap dapat dibedakan ke dalam sikap sosial dan sikap individual. Sikap sosial dapat terlihat dari cara-cara kegiatan yang sama dan berulang-ulang terhadap objek sikap yang dapat berupa benda, tempat, gagasan, situasi atau kelompok (Jalaludin Rakhmat dalam Kulsum, 2014). Terdapat tiga komponen pembentuk sikap yaitu respon kognitif (gambaran cara seseorang dalam mempersepsi objek), respon evaluative afektif (perasaan atau emosi yang dihubungkan dengan suatu objek sikap) dan respon evaluative perilaku (tendensi untuk berperilaku dengan caracara tertentu terhadap objek sikap).

Dalam kaitannya dengan permasalahan lingkungan hidup, sikap dan perilaku masyarakat akan memberikan dampak terhadap kualitas dari suatu lingkungan hidup. Terjadinya relasi timbal balik antara masyarakat dan lingkungan merupakan sesuatu keniscayaan. Hal senada diutarakan oleh Hamzah dalam Palupi (2017) bahwa baik atau buruknya kondisi lingkungan hidup ditentukan oleh sikap dan perilaku masyarakat. Pada akhirnya, perlakuan manusia terhadap lingkungan akan berpengaruh pada kualitas hidup manusia itu sendiri.

\section{Sampah Plastik}

Aktivitas sehari-hari masyarakat selalu memunculkan sampah. Volume sampah yang dihasilkan berbanding lurus dengan semakin tingginya populasi manusia. Meningkatnya volume sampah terjadi karena perilaku dan cara pandang masyarkat yang tidak atau belum berubah. Sampah masih dipandang sebagai sesuatu yang harus dibuang. Selain itu teknologi pengelolaan sampah pun masih belum dimaksimalkan.

Sampah kerap kali dikatakan sebagai limbah karena dianggap sebagai sesuatu yang tidak berguna lagi dan harus disingkirkan. Bentuk limbah adalah: padat, cair dan gas. Dilihat dari bahannya maka terdapat pengkategorian sampah organik atau anorganik. Sampah dapat berupa benda yang terbuat dari material logam atau bukan logam (dikutip dari Rizal, 2011).

Salah satu material yang banyak digunakan sebagai bahan pembentuk suatu benda adalah plastik. Material plastik sangat mudah ditemukan dalam bentuk berbagai benda yang biasa dalam kehidupan sehari-hari. Masifnya penggunaan plastik karena kesan yang ditampilkannya tampak bersih, lebih praktis, mudah diperoleh, lebih murah dan tahan lama.Plastik tergolong pada senyawa polimer sintetik yang memiliki ikatan kimia yang sangat kuat. Plastik yang banyak dipakai adalah plastik non biodegradable yaitu plastik yang terbuat dari minyak bumi. Jenis plastik ini yang tidak dapat terurai secara biologis.

Walaupun banyak memberikan kemanfaatan dalam menunjang kehidupan sehari-hari, dampak negatif yang ditimbulkan dari material plastik sangat merusak. Sampah plastik yang dibuang ke tanah tidak dapat diurai oleh mikroorganisma sehingga merusak kesuburan tanah dan mencemari air tanah. Cara paling mudah untuk melenyapkan plastik adalah dengan membakarnya, tetapi cara ini justru membahayakan kesehatan manusia karena membentuk dioksin, yaitu senyawa yang dapat memicu kanker, hepatitis, pembengkakan hati dan gangguan sistem syaraf (Sirait dalam Putra, 2010).

Sampah plastik yang saat ini sulit dikendalikan adalah kantong plastik bekas. Tingginya penggunaan kantong plastik dan perilaku yang 
pada umumnya hanya sekali pakai langsung dibuang menyebabkan sampah kantong plastik menjadi berlimpah. Sampah kantong plastik lebih banyak dibuang langsung daripada didaur ulang. Tanpa ada upaya nyata dalam menangani sampah kantong plastik maka Indonesia akan menghadapi bencana lingkungan hidup.

\section{Karya Rupa Kontemporer}

Berbeda dengan pandangan seni rupa modern yang menciptakan jarak dan batas antara seni dengan lingkungannya, maka seni rupa kontemporer menempatkan dirinya sebagai produk budaya manusia yang merespon dan mengekspresikan peristiwa sosial dan budaya yang terjadi di masyarakat. Lebih jauh lagi seperti yang disampaikan Nugroho dan Himawan (2014), dalam seni rupa kontemporer proses penciptaan maupun apresiasi karya akan berlangsung secara sistemik serta menyeluruh mencakup idiom-idiom, medium seni, teks dan konteks yang dihasilkan. Refleksi kritis terhadap sistem budaya, ekonomi dam sosial akan mewujud dalam karya seni kontemporer.

Karya-karya seni rupa bertema lingkungan hidup sudah banyak dihadirkan beriringan dengan semakin seringnya permasalahan lingkungan hidup diperbincangkan dalam berbagai forum. Hal ini menandakan adanya kegelisahan yang mendalam terhadap kondisi lingkungan hidup yang dinilai semakin merosot. Seniman-seniman menanggapi permasalahan pemanasan global, kehancuran hutan-hutan tropis, krisis air tanah, sampah plastik dan masalah lingkungan lainnya dalam bentuk karya yang menggunakan beragam medium.

\section{Pembahasan}

\section{Metode Penciptaan Melalui Eksperimen}

Model penelitian yang dilakukan adalah penelitian artistik. Menurut Borgdorff seperti yang dikutip Guntur (2016), dalam konteks akademik dan artistik, penelitian artistik berupaya mengkomunikasikan konten yang menyampaikan pengalaman estetik, praktik kreatif dan proses penciptaan karya artistik.
Untuk mencapai tujuan penelitian artistik maka dilakukan 2 tahap yaitu (1) Tahap penelitian.Pada tahap ini dilakukan penelitian secara komprehensif dan mendalam tentang permasalahan yang menjadi acuan penciptaan karya. Penemuan makna dan perumusan konsep karya menjadi tujuan dari tahap ini. (2) Tahap penciptaan.Pada tahap ini dilakukan penciptaan karya dengan bertitik tolak pada permasalahan yang diangkat dengan tujuan menerjemahkan konsep dan memberikan makna.

Berikut bagan dari proses penciptaan karya yang diadaptasi dari teori proses penciptaan yang disampaikan oleh Konsorsium Seni (Junaedi, 2016).

Tahap persiapan berupa pengamtan atau pengumpulan informasi dan gagasan. Tahap elaborasi yaitu berbentuk penetapan gagasan pokok melalui analitis, integrasi, abstraksi, generalisasi dan transmutasi. Berikutnya, sintesis yaitu tahap mewujudkan konsepsi karya seni. Keempat, perealisasian konsep ke dalam berbagai media seni. Kelima, penyelesaian bentuk akhir karya seni.

\section{Persiapan}

Sebagai tahap persiapan penciptaan telah dilakukan pengamatan di kawasan Ciroyom yang meliputi pemukiman dan tempat pembuangan sampah (TPS) Ciroyom. Selain itu dilakukan wawancara kepada Ketua RW 04, Ketua RT 05, Ketua

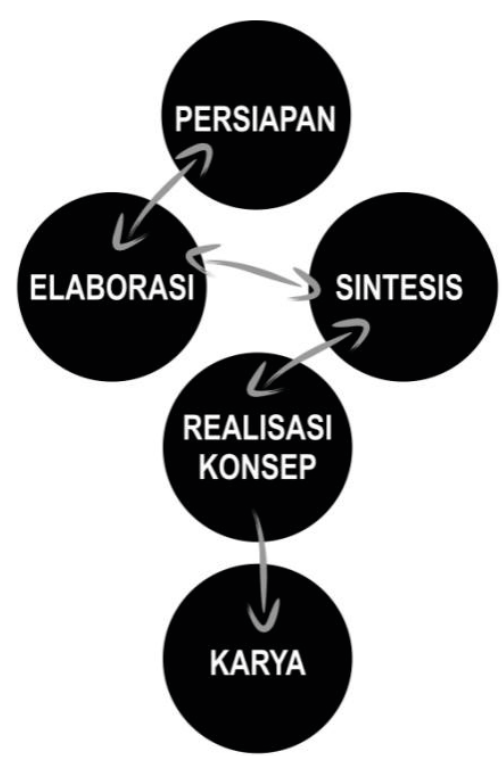

Gambar 3. Proses penciptaan karya. 
PKK RW 04, Kepala SDN Ciroyom, Ketua Seksi Pengembangan Teknologi Tepat Guna Kecamatan Andir, Kepala Seksi KebersihanKecamatan Andir dan beberapa warga yang bermukim di Ciroyom. Pengamatan dan wawancara dilakukan dalam rentang September 2017-April 2018

Dari pengamatan di kawasan pemukiman Ciroyom tampak sampah-sampah plastik yang bertebaran di sekitar gang utama.Di kawasan pemukiman Ciroyom terdapat banyak warung dan pedagang-pedagang kaki lima di sekitar SDN Ciroyom yang menjajakan jajanan. Perilaku sebagian masyarakat tampaknya masih membuang sampah-sampah kemasan tidak pada tempatnya. Di depan rumah tampak kantung plastik yang digunakan untuk mengumpulkan sampah domestik. Sampah yang dikumpulkan kemudian diambil oleh petugas pengambil sampah yang berkeliling mengitari pemukiman warga.

Dari pengamatan di TPS terlihat sampah plastik cukup banyak. Pemulung melakukan pemisahan sampah plastik yang bernilai ekonomis. Kantung plastik (keresek) sendiri dinilai tidak dapat dijual sehingga dibiarkan untuk diangkut ke tempat pembuangan akhir (TPA). Di lokasi TPS tampak berbagai aktivitas.Selain kegiatan pembongkaran, pengangkutan dan pemilahan sampah, tampak aktivitas sebuah keluarga yang menjual makanan dan minuman. Terlihat pula beberapa anak sedang bermain.

\section{Elaborasi}

Dari kondisi yang teramati serta wawancara dengan kepada tokoh kunci masyarakat dapat dideskripsikan bahwa permasalahan sampah merupakan permasalahan yang sulit ditanggulangi dan membutuhkan kerjasama dari semua elemen masyarakat. Masyarakat masih berpersepsi bahwa sampah adalah sesuatu yang harus dibuang. Sebagian mengetahui pemilahan sampah tetapi belum dilakukan dengan berbagai alasan. Dampak langsung dari kondisi ini adalah besarnya volume sampah yang terkumpul di TPS. Dari hasil temuan maka dikembangkan gagasan untuk penciptaan karya rupa yang merespon permasalahan lingkungan yang ditimbulkan oleh sampah kantong plastik.

\section{Sintesis}

Dampak negatif dari sampah kantong plastiksangat mempengaruhi mutu lingkungan hidup. Kualitas tanah yang semakin menurun karena sampah kantong plastik yang sulit diurai. Volume sampah kantong plastik yang semakin besar telah menciptakan ketidakseimbangan ekosistem. Penggunaan kantong plastik menunjukan adanya kekuatan besar yang mempengaruhi kondisi lingkungan hidup. Dari pemikiran tersebut maka konsep karya yang diangkat adalah dominasi.

Dominasi dalam kajian teori kritis dikatakan sebagai suatu bentuk kekuasaan yang memberikan pengaruh terhadap segala aktivitas masyarakat dan masyarakat cenderung untuk menerimanya tanpa diikuti dengan kesadaran yang utuh. Bentuk dominasi yang berkembang di masyarakat mewujud dalam berbagai variasi seperti dominasi dalam sistem birokrasi, ilmu pengetahuan, ideologi, hukum pasar, dsb. Dominasi pada akhir memunculkan disorientasi, alienasi serta budaya tunggal yang mematikan budaya pluralisme (Suka, 2012).

Plastik sebagai produk industri semakin mendominasi kehidupan manusia. Disadari atau tidak masyarakat telah masuk kekondisi ketergantungan terhadap plastik yang akut. Material plastik seakan-akan menjadi material yang tidak bisa tergantikan. Sebagai contoh bagaimana enggan dan sulitnya masyarakat mengurangi kebiasaan menggunakan kantong plastik. Plastik pada akhirnya membentuk suatu masyarakat yang apriori terhadap permasalahan lingkungan.

\section{Realisasi Konsep}

Dengan mengacu pada konsep karya yang mengangkat tentang dominasi plastik, langkah selanjutnya dilakukan adalah melakukan eksplorasi gagasan visual yang meliputi aspek bentuk, warna dan tekstur. Selain itu dieksplorasi pula kemungkinan material, media dan teknik yang digunakan. Agar pesan dari karya dapat tersampaikan serta memberikan pengalaman estetik yang berbeda kepada masyarakat maka material utama yang digunakan adalah sampah 
kantong plastik yang dipadukan dengan maerial pendukung lainnya. Sampah kantong plastik ini akan ditampilkan secara dominan.

\section{Penciptaan Karya}

\section{Karya 1 (Kisah dari Sudut Kota I)}

Karya ini mengungkapkan tentang dominasi budaya penggunaan plastik yang menghasilkan sampah-sampah plastik. Pada karya ini ditampilkan citra visual yang kontradiktif yaitu citra visual yang berasal dari material sampah plastik dengan daun pisang yang telah meranggas. Sampah plastik dan daun pisang meranggas memiliki karakteristik yang berbeda. Sampah plastik merupakan produk industri yang memiliki sifat sangat sulit diurai, sementara daun pisang merupakan bagian dari benda organik yang mudah diurai. Penggunaan material yang berbeda ini memiliki pesan simbolik yang menyampaikan alam saat ini menghadapi krisis dan ancaman dari semakin banyak atau dominannya penggunaan material plastik yang tidak diikuti oleh kesadaran dalam hal pengelolaannya.

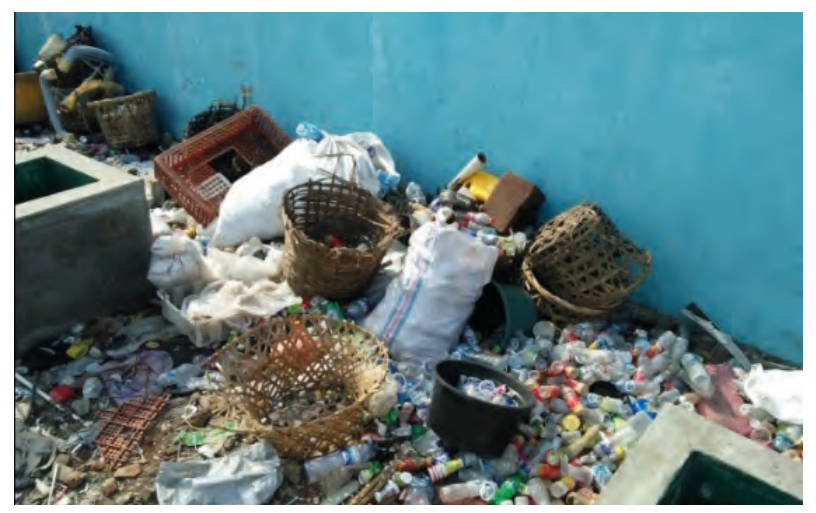

Gambar 4. Material sampah sebagai bahan untuk karya yang terdapat di sekitar TPS.

(Sumber: dokumentasi pribadi)

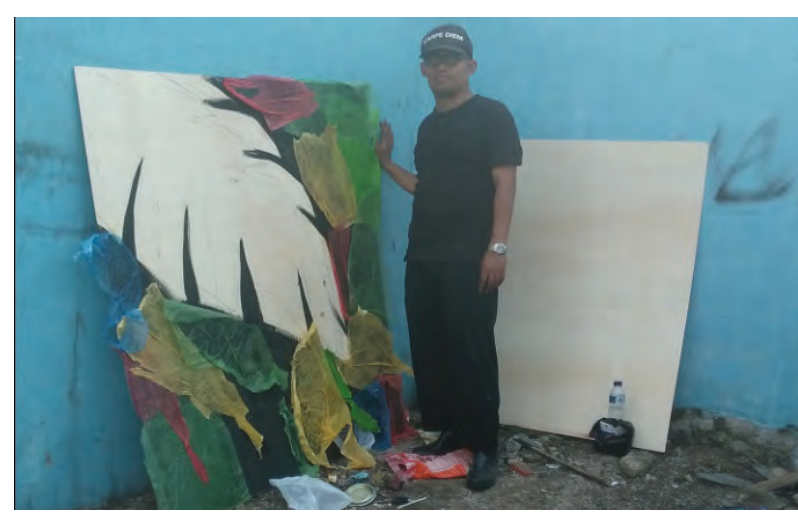

Gambar 5. Tahap pengerjaan karya yang dilakukan di TPS. (Sumber: dokumentasi pribadi)
Penciptaan karya dilakukan di tempat pembuangan sampah sementara Ciroyom. Proses penciptaan karya ini melalui tahap pemilihan dan pemilahan material yang akan digunakan. Material yang dipakai dipakai adalah kantong plastik bekas yang ditemukan disekitar tempat pembuangan sampah, kemasan-kemasan bekas dari produkproduk consumer goods dan daun pisang yang telah lapuk dan meranggas. Kantong plastik kemudian ditempel di media multiplek berukuran $120 \times 140$ $\mathrm{cm}$ dengan mempertimbangkan komposisi warna dan tekstur plastik. Di beberapa bagian dilekatkan pula kemasan-kemasan plastik untuk memperkuat citra sampah. Langkah terakhir, pada bagian-bagian tertentu disapukan cat akrilik untuk menciptakan kesan kedalaman.

\section{Karya 2 (Kisah dari Sudut Kota II)}

Karya ini terinspirasi oleh kehidupan beberapa orang anak yang tinggal di sekitar tempat pembuangan sampah. Mereka sangat akrab dengan sampah-sampah plastik yang dikumpulkan oleh orang tua mereka. Tetapi yang ingin disampaikan

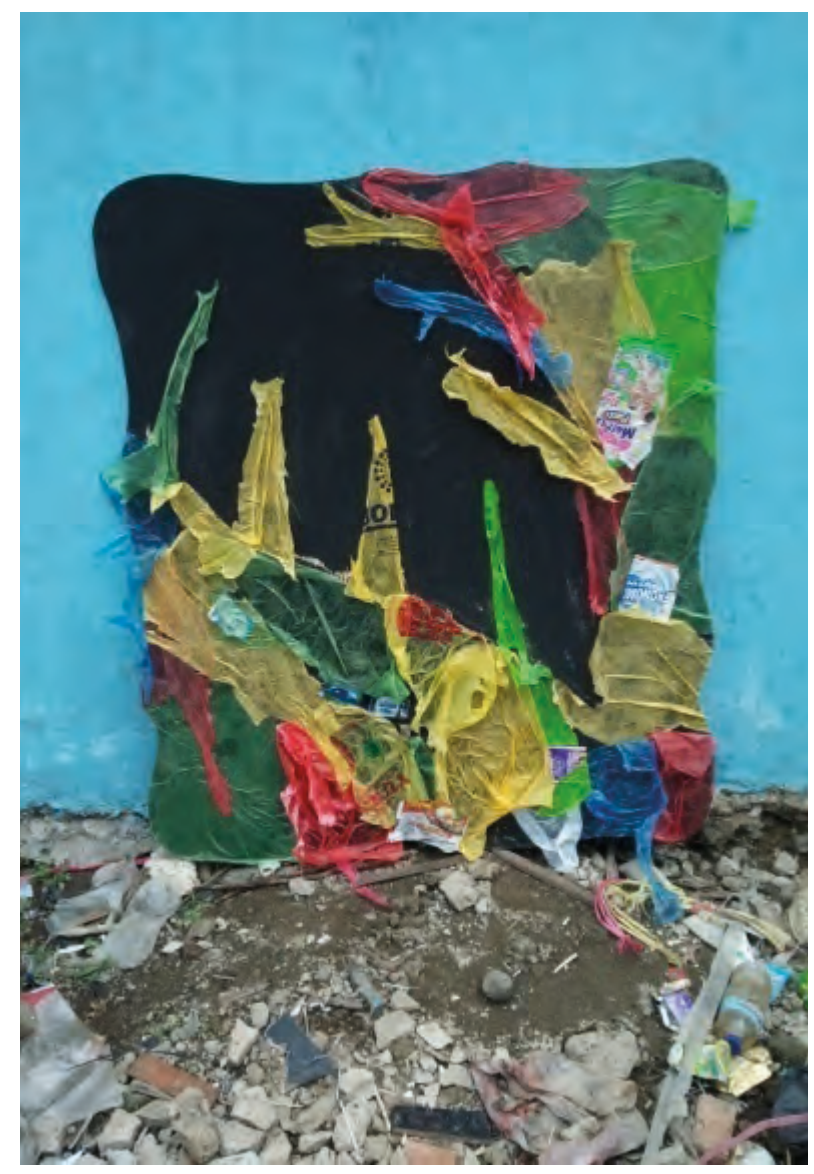




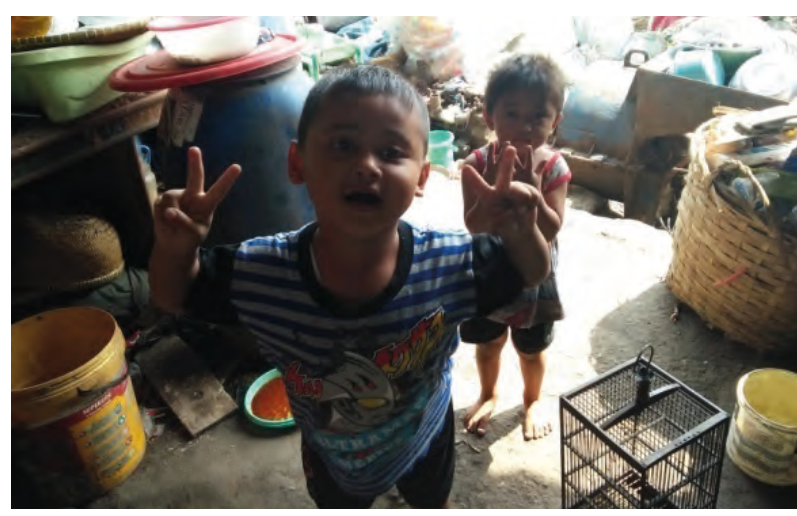

Gambar 6. Sikap anak yang berada di TPS Ciroyom dan Karya 2 yang terinspirasi oleh perilaku anak di lokasi TPS Ciroyom. (Sumber: dokumentasi pribadi)

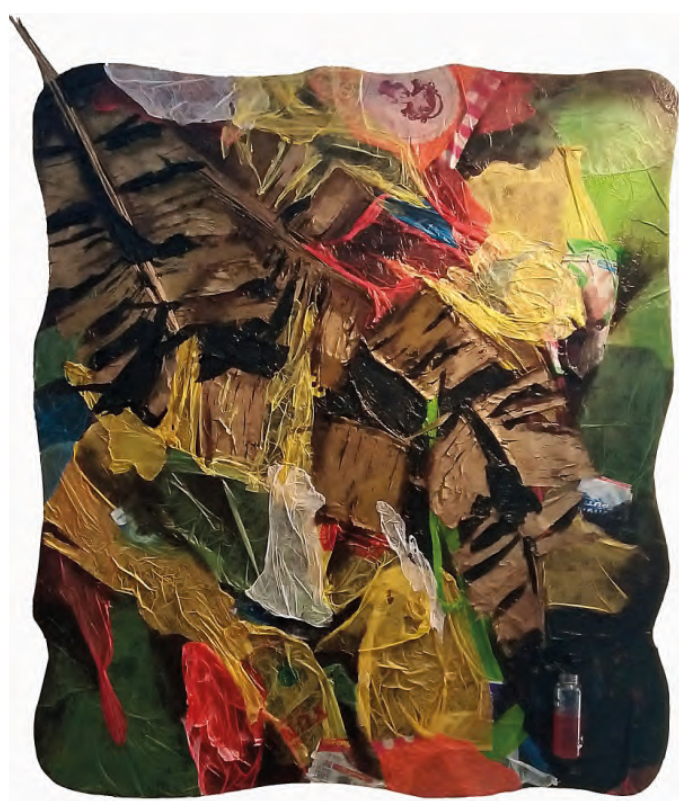

Gambar 7. Karya 1 yang telah selesai. (Sumber: dokumentasi pribadi)

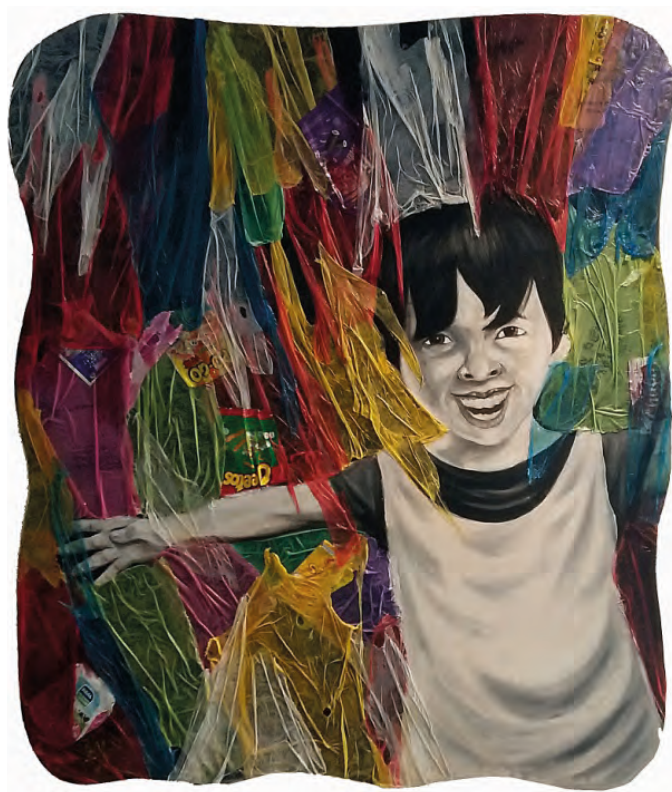

Gambar 8. Karya 2 yang telah selesai. (Sumber: dokumentasi pribadi) melalui karya ini adalah lingkungan yang telah terkontaminasi sampah plastik sebagai ancaman yang nyata untuk masa depan manusia. Dihadirkannya figur seorang anak pada karya ini adalah simbol dari masa depan.

Pada karya 2 (berukuran 110 x $110 \mathrm{~cm}$ berbahan multiplek) ditampilkan objek figuratif yaitu sosok anak kecil dengan ekspresi yang bahagia. Sosok tersebut tampak sedang merentangkan tangan. Citra visual dominasi dihadirkan dengan beberapa langkah. Pertama, dengan meletakan sosok anak kecil di pojok kiri bawah bidang karya yang memunculkan kesan ditekan.

Disekitar sosok dikomposisikan material kantong plastik dalam berbagai ukuran dan warna. Agar kesan menekannya maka dimunculkan tekstur yang tercipta dari lipatan plastik. Tekstur ditampilkan menyerupai garis-garis yang mengarah pada sosok anak kecil. Di beberapa bagian sosok anak kecil, terlapisi plastik untuk memberikan kesan adanya suatu keadaan yang menjerat.

Langkah berikutnya dengan menampilkan warna yang kontras antara sosok anak kecil ditampilkan dengan warna monokromatik putihabu-hitam dan dipadukan dengan warna-warna dari kantong plastik seperti merah, kuning, biru dan hijau. Komposisi warna dalam karya ini secara simbolik menyampaikan bahwa hal yang tampak menarik belum tentu memberikan dampak yang baik.

\section{Simpulan}

Proses penciptaan karya rupa dengan menggunakan sampah plastik telah memberikan pengalaman artistik bagi kreator. Interaksi langsung dengan permasalahan yang terjadi di masyarakat terkait dengan permasalahan lingkungan hidup merupakan tahap penting dari proses penciptaan. Terdapat sisi objektif dan subjektif saat berupaya memahami permasalahan lingkungan hidup yang terjadi di masyarakat.

Segala sesuatu yang terlihat maupun dirasakan kemudian dituangkan dalam karya rupa yang memanfaatkan material sampah plastik. Proses pencarian dan pemilahan material sampah plastik dan material yang lainnya menjadi tantangan tersendiri. 
Sampah plastik yang sudah berada di tempat pembuangan sampah berbeda dengan plastik yang baru. Material sampah plastik telah mengalami perubahan yang mempengaruhi pada warna maupun pada sisi elastisitasnya. Dengan melakukan eksperimen yang menggunakan material yang demikian maka proses mempertajam intuisi dalam berkaryapun terjadi. Material-material tersebut menjadi stimulus untuk terus mengeksplorasi kemungkinan kemunculan citra visual yang tak terduga.

\section{Ucapan Terima Kasih}

Kementerian Riset, Teknologi dan Pendidikan Tinggi bersama Lembaga Pengelola Dana Pendidikan sebagai penyelenggara Beasiswa Unggulan Dosen Indonesia (BUDI).

Rektor Universitas Komputer Indonesia yang telah mendukung kegiatan-kegiatan yang terkait dengan studi lanjut Program Doktoral.

Ketua RW 04, Kepala TPS Ciroyom dan pengurus lainnya serta para warga yang telah bersedia membantu pelaksanaan penelitian lapangan.

\section{Kepustakaan}

Damajanti, I. 2006. Psikologi Seni. Bandung: Kiblat.
Damsar dan Indrayani. 2017. Pengantar Sosiologi Perkotaan. Jakarta: Kencana.

Guntur. 2016. Metode Penelitian Artistik. Surakarta: ISI Press.

Junaedi, D. 2016.Estetika: Jalinan Subjek, Objek dan Nilai. Yogyakarta: Artciv.

Kulsum, U. dan Jauhar, M. 2014. Pengantar Psikologi Sosial. Jakarta: Prestasi Pustakaraya

Nugroho, B.A. dan Himawan, W. 2014. Visual Tradisi dalam Karya Seni Lukis Kontemporer Sebagai Wujud Artistik Pengaruh Sosial Budaya. Journal of Urban Society's Arts, Volume 1 Nomor 4, 99-109.

Palupi, T. dan Sawitri D. 2017. Hubungan Antara Sikap Dengan Perilaku Pro-Lingkungan Ditinjau dari Perspektif Theory of Planned Behavior. Proceeding Biology Education Conference Volume 14, Nomor 1, 214- 217. Putra, H dan Yuriandala, Y. 2010. Studi Pemanfaatan Sampah Plastik Menjadi Produk dan Jasa Kreatif. Jurnal Sains dan Teknologi Lingkungan, Volume 2, Nomor 1, 21-31.

Rizal, M. 2011.Analisis Pengelolaan Persampahan Perkotaan (Studi Kasus pada Kelurahan Boya Kecamatan Banawa Kabupaten Donggala) Jurnal SMARTek, Vol. 9 No. 2. 155 - 172.

Suka, I.G. 2012. Dominasi dalam Perspektif Teori Kritis. Pustaka. Volume XII No 1. 42 